\title{
Capital, Labor, and the Spoils of War $\star$
}

\author{
MIROSLAV NINCIC \\ The University of Michigan
}

\begin{abstract}
The article deals with certain political and economic consequences of recent American war involvements. It is found that the nation's economy experienced particularly pronounced surges of growth during wartime and certain implications of this fact for both Keynesian and Marxian doctrine are discussed. It is further demonstrated that, contrary to much conventional wisdom, labor rather than business derived the greatest gains from U.S. military interventions abroad - a finding which, while perhaps counterintuitive, can be explained by the joint exigencies of politics and economics in wartime. Finally, while economic considerations may not have influenced the decisions to initiate foreign intervention, it is suggested that they may well have affected the subsequent expansion and duration of military involvement.
\end{abstract}

War has traditionally been an issue which has claimed much of the attention of political scientists concerned with international affairs. The lion's share of their efforts has however been devoted to the study of its causes rather than its effects. A considerable amount of attention has, for example, focused on the empirical correlates of war with the purpose of discerning the pattern of circumstances surrounding its occurrrence. ${ }^{1}$ There have also been efforts at formulating and testing complex causal models of the process leading to the onset of inter-state hostilities. ${ }^{2}$ The issue of the consequences of international conflict has, on the other hand, been somewhat neglected within the discipline. This is not the natural sequence which investigations in the social sciences should be expected to follow. Rather, an understanding of the difference which some social phenomenon makes would seem naturally antecedent to any investment into the study of its causes. The preferential focus on causes rather than consequences is nonetheless understandable - after all, the fact that war produces, as its principal effect, the destruction of life and property seems obvious and requires no elaborate demonstration. Yet, as we probe deeper and as we broaden the scope of our concerns, it becomes harder to feel confident about the

* I would like to thank Peter Wallensteen and Bruce Russett for helpful comments on an earlier draft of the article. adequacy of our knowledge. What, for example, is the immediate effect of international conflict on national political institutions? What are the long term effects of war on societal development? Who, if anyone, benefits from wars? Although such matters have occasionally been addressed, ${ }^{3}$ the range of questions to which we have no adequate and tested answers is surprisingly vast and this fact alone should justify additional efforts in this area.

The aim of this brief study will be to assess some effects of recent U.S. war involvements on the country's economic growth and, more specifically, on the distribution of national income between major social groups. Certain directly political implications of these consequences will also be discussed. Throughout, the study will focus on the basic structure of the relevant processes and will aim for presentational clarity. The utility of such an inquiry should not be very hard to justify. Since war is the most dramatic, costly, and apparently aberrant form of interaction between states and since, furthermore, the pursuit of material growth and of some conception of distributional equity is one of the most permanent and accepted aims of political activity within nations, it should be of considerable interest to attempt to relate the two. Another, and just as important payoff of such a study might be to shed some new light on the pattern of domestic inducements and 
constraints on American participation in foreign wars (thus linking the matter of cause with that of consequence).

Before proceeding too far, a number of caveats are in order. The United States is, from an economic point of view, hardly a representative nation. Nor has U.S. participation in the three wars considered here (World War II, Korea, and Vietnam) necessarily been representative of most involvements in war. None of the wars called for a total commitment of the country's resources nor did they cause any direct destruction of the American homeland (as would have resulted from fighting on the national territory or in, say, bombardment). While it might thus be perilous to generalize very far, the effect of U.S. participation in armed conflict is of obvious importance in and of itself. Furthermore, certain conclusions reached on this empirical basis might apply to future American experience should the country again be involved in extended military intervention abroad.
War and U.S. economic growth

The major purpose of economic activity is to augment material wealth. While this has long been considered the responsibility of essentially private actors, political authorities are increasingly being held accountable by their publics for providing the conditions of prosperity at the national level. Economic activity has become more and more politicized and, accordingly, a growing number of political scientists are delving into the political context and ramifications of economic performance. ${ }^{4}$

Intuitively, it may seem apparent that war (even of a limited nature) must have detrimental effects on a nation's economy. Capital is, after all, diverted from its normal uses, private consumption is usually curtailed, price mechanisms are often suspended in market economies, and so forth. Intuitive impressions notwithstanding, there are strong empirical and theoretical reasons for thinking otherwise. While some of the relevant theory will be described in this section, it might be useful to begin by examining the actual data,

Fig. 1.

U.S. Economic Growth: $1933-1977$

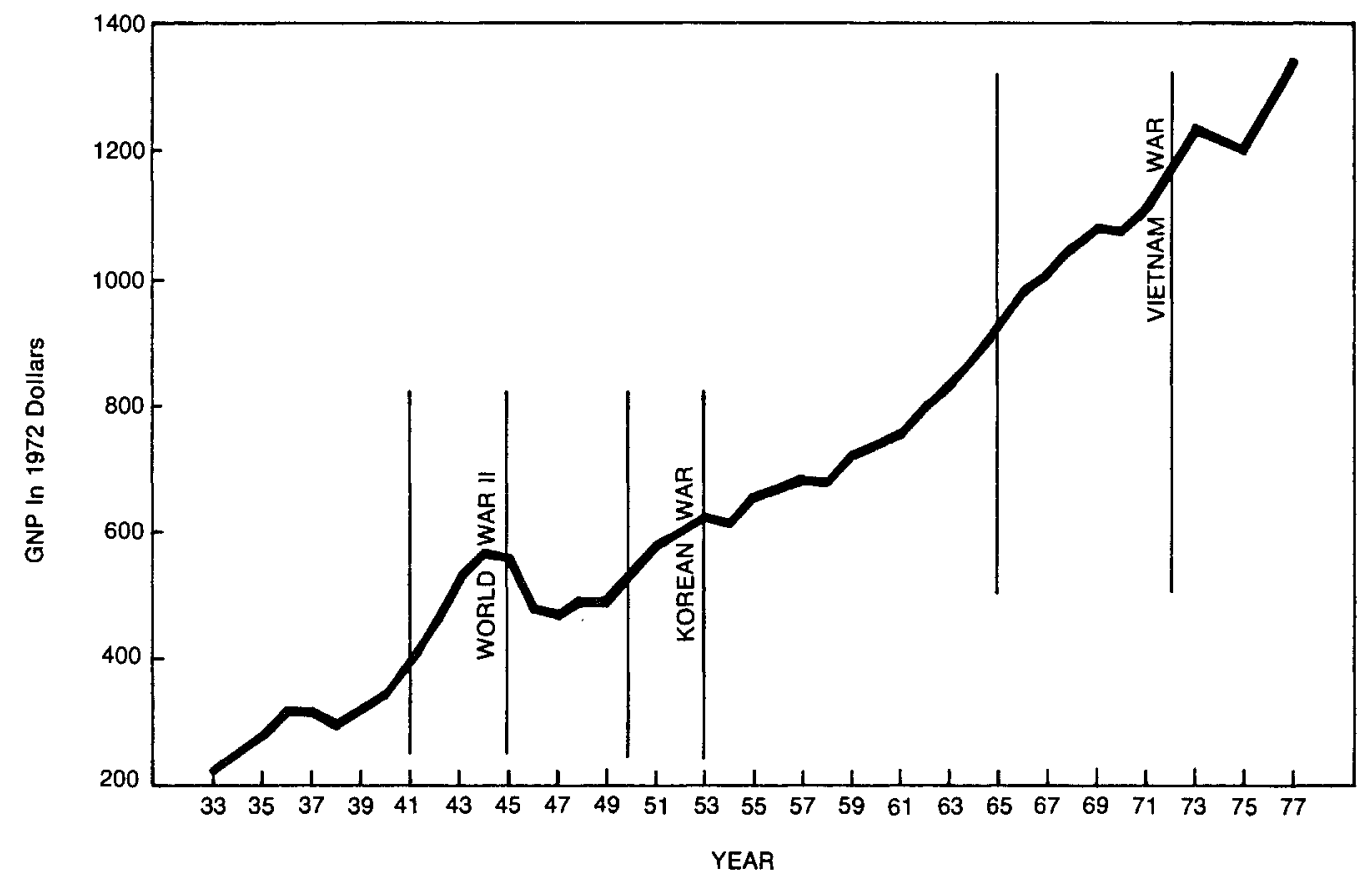


Figure 1 displays the trajectory of the Gross National Product of the United States (expressed in constant 1972 dollars) since the introduction of New Deal economics in 1933 or, in other words, since the beginnings of contemporary economic policy in this country. A visual inspection of the time series does suggest a surge in national income during wartime and relative to the preceding period, a surge which was particularly pronounced during the first two wars but which is discernible in the Vietnam case as well. In concrete numerical terms, the average yearly wartime increase in constant GNP was 37.8 billion dollars; during periods of peace an average of only 16.6 billion dollars was added to GNP yearly. War, in other words, was associated with absolute increases in national wealth which were considerably higher than those which obtained in peacetime. At a lower level of aggregation, Table I compares these same average yearly increases during each of the three wars with the comparable figure for the same number of previous years.

Table I. Average Yearly Change in Gross National Product*.

\begin{tabular}{lccc}
\hline & $\begin{array}{c}\text { During } \\
\text { War }\end{array}$ & $\begin{array}{c}\text { Years } \\
\text { Preceding } \\
\text { War }\end{array}$ & $\begin{array}{c}\text { Differ- } \\
\text { ence }\end{array}$ \\
\hline World War II & $41-45: 43.1$ & $36-40: 13.0$ & 30.1 \\
Korean War & $50-53: 32.8$ & $46-49:-16.9$ & 49.7 \\
Vietnam War & $65-72: 37.1$ & $57-64: 25.7$ & 11.4 \\
\hline
\end{tabular}

* GNP data (expressed in constant 1972 dollars) are from The Economic Report of the President 1978 (Washington, DC).

The difference is obviously rather large; while it is greatest in the case of the Korean War (reflecting the very poor performance of the economy during the preceding period), the difference is substantial as far as the other two wars go as well. It is also worth noting that the pre-World War II period taken here does not include the most critical years of the Great Depression (in fact, I begin the series in 1933 rather than 1929 , when the needed data are already available, in order to avoid the bias which might otherwise have been introduced).
From another angle, table II presents comparisons (1933-1977) between wartime and peacetime values for average changes in constant GNP ( $\widehat{\triangle G N P}$ ) as well as for three other indicators of economic performance: average yearly change in personal income in billions of constant dollars $\widehat{(\Delta y)}$, average yearly rate of unemployment $(\% \mathrm{u})$, and average yearly increase in the Industrial Production Index

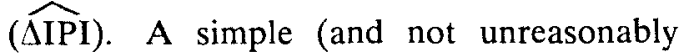
demanding in terms of its prior assumptinos) non-parametric $U$ statistic is also presented; its value provides a measure of the significance of the discrepancy between the wartime and peacetime distributions of the values of each of the four variables.

Again, there is a clear difference between the performance of these measures in war and in peace. Personal income and industrial Table II. Indicators of Economic Performance.*

\begin{tabular}{|c|c|c|c|c|}
\hline & $\triangle \widehat{G N P}$ & $\widehat{\Delta y}$ & $\widehat{\Delta \mathrm{IPI}}$ & $\widehat{u} \%$ \\
\hline War & 37.8 & 23.8 & 4.1 & 4.1 \\
\hline Peace & 16.6 & 11.8 & 2.0 & 9.3 \\
\hline $\begin{array}{l}U= \\
\text { sig }=\end{array}$ & $\begin{array}{r}132 \\
.013\end{array}$ & $\begin{array}{r}144 \\
.03\end{array}$ & $\begin{array}{r}161 \\
.07\end{array}$ & $\begin{array}{r}75 \\
.0001\end{array}$ \\
\hline
\end{tabular}

* Data for $\widehat{\triangle \mathrm{GNP}}, \widehat{\triangle \mathrm{Y}}$ and $\widehat{\mathrm{u} \%}$ are taken from: The Economic Report of the President for 1969 and 1978. The data for $\widehat{\triangle I P I}$ are from: The Handbook of Basic Economic Statistics - July 1978 (Bureau of Economic Statistics Inc.).

production (as measured by the index) have both tended to increase considerably during wartime; unemployment has been less than half its peacetime magnitude. The level of significance for these differences is very respectable in terms of most conventionally accepted levels.

Thus far, the conclusion seems inescapable: war has been associated with periods of exceptionally rapid growth across some important indicators of economic performance. Whatever else they may have been, America's economic wars were not economically neutral. Nevertheless, this statement should not be endowed with excessive meaning. Quite apart from the associated human losses, 
growth in such a context has not necessarily involved a qualitative improvement in American economic life. To begin with, wartime income growth does not invariably go hand in hand with a corresponding movement in disposable personal income, as this will depend on the method by which the war is financed. If this is done through taxation, fiscal claims on personal income may neutralize the effect of overall increases. If, on the other hand, the government relies on deficit spending, then the differences between movements in the two quantities may be slight. Secondly, the nature of the increased economic activity means that the quantity and quality of available civilian goods and services will probably not improve (although income gains could, in principle, be used for purchases from abroad). Finally, none of the economic gains would be anticipated in anything but a limited war (which involves no destruction of the economic infrastructure and capital stock).

What the evidence does imply is that additional claims were placed on the nation's productive capacity, that available economic resources were used more intensely and that eventually, expanded productive capacity was established in response to increased needs.

This, however, is simply an empirical statement, it tells us what happened but does not enlighten us as to the nature of the link between war and economics. Although no definitive answers can be given, there are theoretical arguments, based on both Marxian and Keynesian doctrine, which suggest that secular stagnation may have been the rule in the absence of occasional warfare. While the reader may be familiar with these arguments, a brief recapitulation should be useful.

Contemporary Marxian authors do not always constitute a uniform school, yet many of their misgivings concerning the viability of capitalist economies focus on the creation of an ultimately unabsorbable economic surplus. One of the most influential treatments of this issue is certainly that provided by Baran and Sweezy in their book entitled Monopol Capital. ${ }^{5}$ The authors define such a surplus as 'the difference between what a society produces and the costs of producing it ${ }^{6}$ and state that, as capitalist economies move from a competitive to an oligopolistic market structure, this surplus will inevitably increase as a proportion of total output. This, in turn, must lead to inventory accumulation and sluggish or negative growth. Barring periods of 'epochmaking innovations' (such as, say, the automobile) growth can be salvaged only by the absorptive effects of war and militarism. This seems, with minor variations, to be the gist of the relevant portions of much Marxian theory in the United States and, in the medium term at least, war is viewed as a palliative (though not a long term cure) to economic stagnation.

Keynesians, as is well known, rejected the classical notions of the automatic adjustment of both employment (via wages) and investment (via interest rates) to levels consistent with health economic activity. Rather, due to the inability of savings to translate automatically into comparable levels of investment, private aggregate demand (the sum of personal consumption and business investment) would fall short of the economy's productive capacity - leading to recession or depression. Government spending should, therefore, supplement private demand to effectuate the necessary adjustment. As wartime spending can perform this function on a very large scale, the Keynesian diagnosis can also be said to support the contention that war can occasionally play an economically useful role. There is, admittedly, nothing in the Keynesian model which implies that other forms of spending may not play the same role with respect to aggregate demand. The issue would, at this point, presumably turn on the extent to which other forms of public spending are effectively available. This is no longer an economic but a political question and an argument might be made that, in the American context, the amount of civilian governmental 
expenditure which would have been needed to fuel economic growth may have been more than would have been ideologically acceptable. $^{7}$

There are thus theoretical grounds for considering limited military engagements as occasionally useful, if perhaps not essential, remedies for stagnationist impulses. ${ }^{8}$ It is not the purpose of this article to provide an exhaustive evaluation of these arguments; it is, however, useful to indicate the extant theoretical structures which may help us evaluate the economic implications of warfare. In addition to drawing our attention to such theories, the modest quantitative exercise contained in this section serves several other purposes.

In the first place, and despite the fact that our major concern here is with wartime effects, the data remind us that the economic gains occasioned by limited warfare have not been reversed upon the termination of hostilities. While this is visually depicted for $\triangle$ GNP in Figure $I$, it is generally true for other indicators of aggregate economic performance as well. Growth rates typically do slow down subsequently (and are occasionally even negative) but there does not seem to have been a return to pre-war levels of economic activity. That the newly developed productive capacity (which is usually developed after the height of the conflict) can be matched by post-war aggregate demand is probably due to three factors. To begin with wartime consumption is usually curtailed creating a situation of pent up consumer demand - with peace, it is suddenly released fueling growth through private demand. Further with the exception of the Vietnam war, military spending displayed a 'ratchet effect' by remaining at a level far in excess of pre-war norms, thus perpetuating some of the conflict's economic effects. Finally, wars have typically served the purpose of legitimizing higher levels of welfarerelated expenditure as the least privileged segments of society were usually called upon to bear the brunt of the human losses; thus even as military spending decreased, public spending for civilian purposes was in a position to maintain adequate levels of aggregate demand.

Secondly, in addition to extending our insights beyond the actual duration of the wars, the data highlight the absolute magnitudes of the changes in the economy which can be associated with the actual hostilities. There is even some evidence that these magnitudes came as a surprise to those most closely associated with the functioning of the economic system. Arthur Okun, President Kennedy's principal economic adviser, recalls that with the onset of full scale U.S. involvement in Vietnam:

Economic activity zoomed from mid 1965 into early 1966 ... In the fourth quarter G.N.P. rose by the largest amount in history. Unemployment fell to 4.0 percent of the labor force by year end. This leap exceeded anyone's expectations or desires. 9

And, furthermore:

In the view of the American businessman, the initial increments to the defense budget virtually eliminated any danger of recession or sluggish growth in 1966. A high floor was established under the economy and the downslide risks essentially disappeared. 10

In the third place, and this is obviously most relevant to our present concerns, the detection of substantial increases which are associated with warfare naturally leads to the important question of how these gains are distributed. An answer to this question might shed some additional light on the nature of the socio-economic system and perhaps hasten our understanding of the relative interest which foreign military involvement can present for some major scoial groups.

\section{Who gains from war?}

There are a number of approaches to the question of how gains from war-induced growth are apportioned by the socio-economic system, and the choice of any particular approach should be guided by conceptual and substantive concerns. One might, for example, focus on the distribution of 
gains between different regions (e. g., between the West Coast and the Northeast), or one might attempt to assess the relative gains acquired by different branches of economic activity (e. g., the aerospace industry versus the construction industry), one might, furthermore, focus on the differential impact of war on various social strata, and so forth. In short, there are virtually as many ways of slicing into the matter as there are manners of categorizing the components of a society. Further complicating the issue is the fact that short term gains (or losses) may well be reversed in the longer run - hence an explicit time frame is needed as well.

For purposes of this study, the focus will be on the economic gains, defined as growth in respective shares of national income, accruing to capital and to labor in the period of the war's actual duration. There are two reasons for this choice. Capital and labor are, first of all, two major factors of production; accordingly, payments to capital (profits) and compensation of employees (wages) have together represented roughly 80 percent of U.S. national income during most of the period considered here. If income growth accelerates in wartime, it should then be interesting to discover how the accretions to national wealth are distributed between its two major p;roducers. Another reason for the emphasis on capital and labor derives from the simple fact that the issue of their relative position has been at the heart of some of the most important debates in political theory and political economy during the past century, a debate which is perpetuating itself as labor ceases to be defined in narrow 'blue collar' terms. ${ }^{11}$ While the controversies have often pitted ideological left against ideological right, a fair amount of divergence has existed within doctrinal groupings as well.

Despite certain fleeting allusions in the literature to war's effect on social equality in general, the issue has not been placed in the specific context of the relative position of capital owners and wage earners. In attempting to acquire a first grip on the problem, it is therefore necessary to proceed in a slightly round-about manner. The comparison of economic growth rates in war and in peace yielded the conclusion that, during recent American history, war has been associated with visible ecenomic surges. If one is willing to entertain the possibility of a causal link, it may be useful to approach the matter by relying on that body of literature which deals with the question of how the fruits of upswings in economic cycles in general are apportioned between profits and wages.

Perhaps the best known position in this regard is that of Marx, who asserted that workers rather than capital owners are the principal beneficiaries of periods of economic boom. The explanation, of course, lies in the fact that during periods of cyclical upturns the 'reserve army of the uemployed' is sufficiently reduced to strengthen labor's hand in its confrontations with capital, thus enabling wage earners to obtain an increased share of the national income. ${ }^{12}$ While most of Marx's followers have naturally concurred with this position, there have also been exceptions. Michael Kalecki, for example, has maintained that, in a context characterized by monopolistic pricing, businessmen can successfully pass on increased labor costs to consumers, thus ensuring a simultaneous gain for both profits and wages. ${ }^{13}$ Many Keynesian liberals, on the other hand, have regarded labor as the losing party during the expansionary phase of the business cycle. This has been based on the premise that the inflationary pressures which typically accompany this phase tend to swell profit rates while reducing the real value of nominal wage increases. ${ }^{14}$

A more recent perspective strikes a compromise of sorts between these positions. According to Albert Burger ${ }^{15}$ (an economist) and Douglas Hibbs ${ }^{15}$ (a political scientist), relative gains will differ depending on whether the economy is at an early or an advanced stage of the upswing. At the beginning of a period of expansion, employers increase the utilization rate of labor while maintaining existing levels of employ- 
Fig. 2.

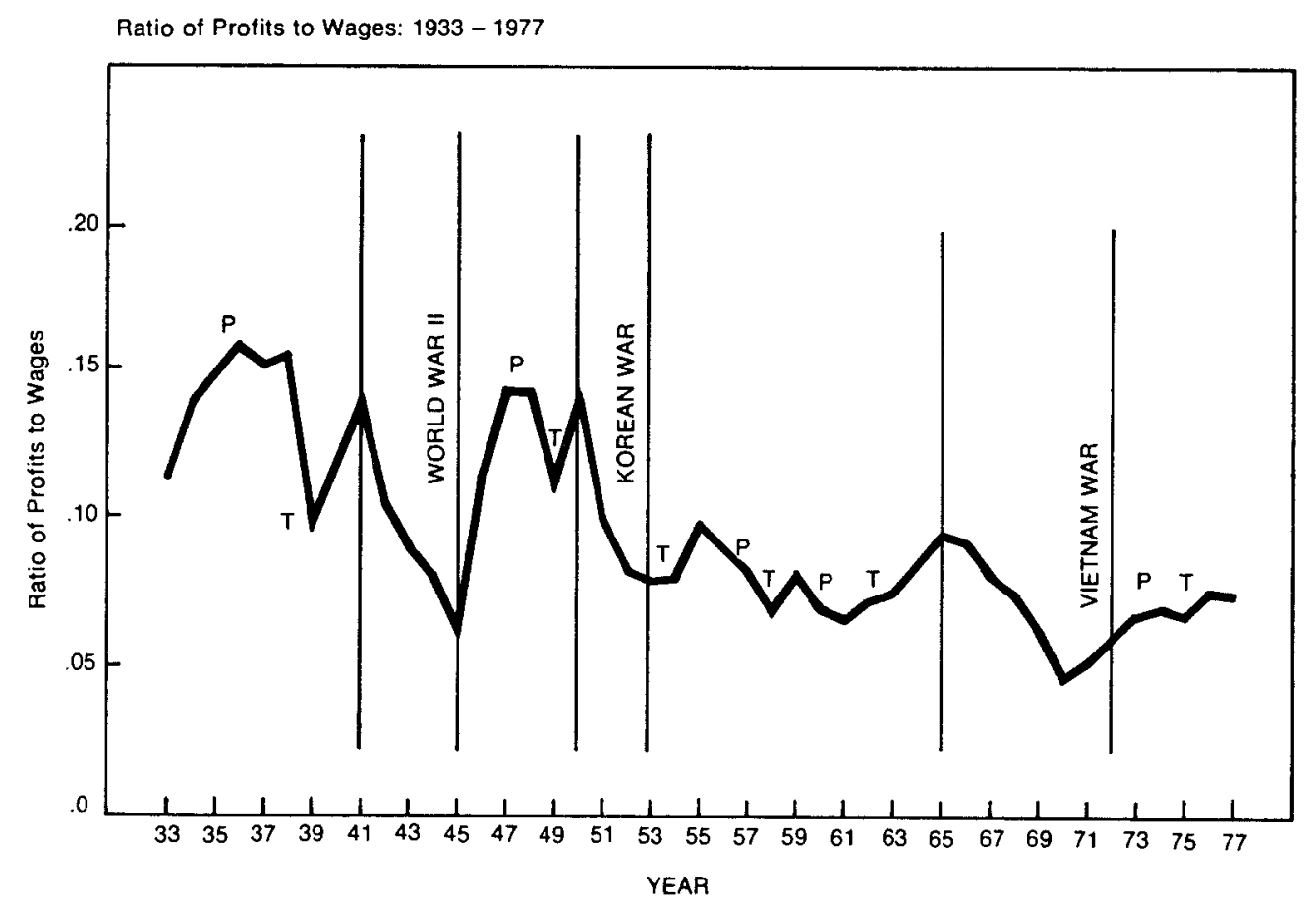

P: Peak in business cycle.

T: Trough in business cycle.

ment - thus raising productivity and profits (but not necessarily wages). As the expansion continues, it becomes necessary to hire additional and often less well qualified employees; consequently, productivity tends to decline while the tighter labor market enables unions to bid wages up and to squeeze profits.

There are thus divergent perspectives on the relative gains claimed by profits and wages during periods of economic expansion. In order to assess how well these theories fare in the particular case of war-induced growth, it will be helpful to examine the movement over time of the ratio of profits to wages in the national income $(\mathrm{p} / \mathrm{w})$, and to closely observe the particular nature of this movement in wartime. A downturn in the ratio would signifiy that the share of wages was increasing, an upturn would indicate a more rapid growth of profits. The data are presented in Figure 2 and a preliminary visual inspection of the trajectory yields three suggestions:

In the first place, this ratio has been experiencing an evident long term decline. Labor, in other words, appears to have been doing even better as compared to capital. This trend, however, has been documented and described elsewhere and will not be dealt with any further here. ${ }^{17}$

A second conclusion is that, during intervals of peace, the ratio has fluctuated rather sharply (albeit around a declining trend). The general tendency, furthermore, has been for upturns (favoring profits) to characterize the early phases of an expansionary period, and for downturns (increasing share of wages) to occur closer to the peak and to continue on down into the trough. In peacetime, therefore, the positions of Burger and Hibbs are borne out.

Finally, and this is most relevant to our concerns, this ratio experiences substantial 
and sustained declines during periods of active military involvement abroad. In other words, increases in the share of wages has a pronounced tendency to outrun changes in the share of profits during wartime. The principal beneficiary of war-induced growth in America seems thus to have been the wage-earner rather than the profit-taker (squarely contradicting the lore of some prevalent views). ${ }^{18}$

Another useful manner of describing this situation is to consider that the ratio of profits to wages can experience either an increase $\left(\Delta^{+}\right)$or a decrease $\left(\Delta^{-}\right)$in any given year. One might then inquire what the odds of one or the other occurring should be, both in war and in peace. On the basis of the visual analysis, the following two hypotheses can be advanced:

(a) In wartime, the odds should favor a decrease rather than an increase in the ratio.

(b) In peacetime, the odds should neither clearly favor an increase or a decrease since the ratio will primarily move in conjunction with the business cycle).

A pair of $2 \times 2$ tables are provided in Table II. The first (a) contains the number of increases and decreases in war and in peace, the second (b) displays the proportions corresponding to these quantities.

Table III. The Profits to Wages Ratio in War and Peace.

\begin{tabular}{lcccc}
\hline & & (a) & \\
War & $\Delta^{+}$ & & $\Delta^{-}$ & Sum \\
Peace & 5 & 12 & 17 \\
\hline Sum & 16 & 12 & 28 \\
\hline
\end{tabular}

\begin{tabular}{lcccc}
\hline & & (b) & & \\
& $\Delta^{+}$ & & $\Delta-$ & Sum \\
War & 0.11 & & 0.27 & 0.38 \\
Peace & 0.35 & & 0.27 & 0.62 \\
\hline Sum & 0.46 & & 0.44 & 1.00 \\
\hline
\end{tabular}

What do these figures reveal? Let us begin with wartime and estimate the probability of a decrease occuring during such a period.
This conditional probabilitiy is given as: $\mathrm{p}\left(\Delta^{-} \mid\right.$war $)=0.27 / 0.38=0.71$, the comparable conditional probabilitiy for an increase during wartime is, on the other hand:

$\mathrm{p}\left(\Delta^{+} \mid\right.$war $)=0.11 / 0.38=0.29$.

Therefore, the odds that a decrease rather than an increase will occur during wartime is: $\mathrm{p}\left(\Delta^{-} \mid\right.$war $) / \mathrm{p}\left(\Delta^{+} \mid\right.$war $)=2.45$.

During a period of military engagement abroad a decrease is thus roughly two and a half times more likely to occur in a given year than an increase, which provides added confirmation of war's tendency to favor labor over capital in the recent American experience. How do these probabilities present themselves in peacetime? We can repeat the exercise as follows:

$\mathrm{p}\left(\Delta^{-} \mid\right.$peace $)=0.27 / 0.62=0.43$, and,

$\mathrm{p}\left(\Delta^{+} \mid\right.$peace $)=0.35 / 0.62=0.55$ thus, $\mathrm{p}\left(\Delta^{-} \mid\right.$peace $) \cdot \mathrm{p}\left(\Delta^{+} \mid\right.$peace $)=0.78$.

Contrary, therefore, to periods of war, intervals of peace tend to favor profits. Nevertheless, the odds of an increase occuring are only slightly better than even, which means that the relationship between war and improvement in the relative position of labor is much stronger than the relation between peace and the gains of profits.

The conclusions are thus confirmed in two quantitative and intuitively meaningful fashions and, on the basis which has already been established, we can discern the nature of the causal process underlying these effects of war. In the first place, involvement in external military conflict means a reduction in unemployment as the level of economic activity rises to meet the new needs and, just as significantly, by the reduction in the supply of labor occasioned by the draft. This reduction in supply coupled with an increase in demand implies an exceptional increase in the cost of labor to employers. While the increased wage bill could theoretically be offset by an increase in productivity, this typically does not occur; in fact, 
a tight labor market often means that many marginally qualified employees must be relied upon for a number of tasks.

More generally, the political context in wartime simply does not encourage large gains for business (which might lead to charges of war profiteering). As the government strives to control the inflation which inevitably accompanies wars, it seems, for example, easier and more acceptable to act decisively on profits rather than on wages. A tight labor market does not necessarily imply a simultaneous shortage of capital the growth in labor's bargaining power is thus not matched by a similar increase for business (though this would not be logically excluded). It is, moreover, the average wageearner rather than the capital-owner who bears the brunt of actual combat. The government, for its part, must mobilize public support for the war, and its attempts to do so are naturally directed toward the broad rather than the narrow segments of this public (i. e., toward wage earners rather

Fig. 3.

Difference in \% growth rates in war and peace by sector

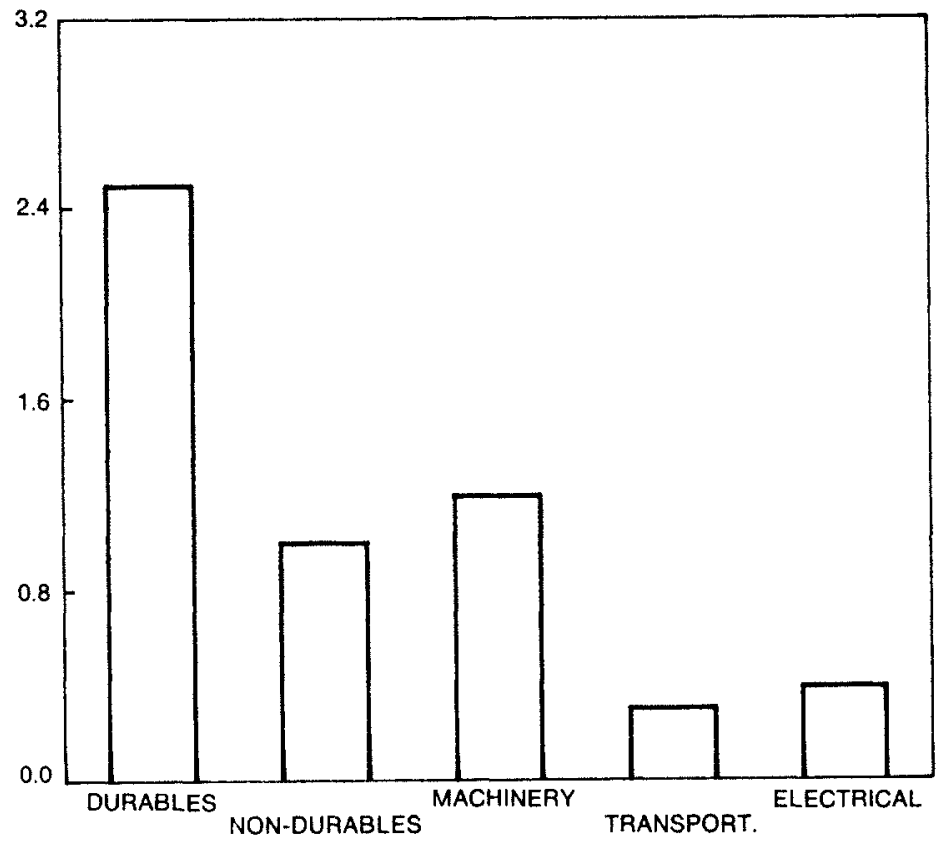

On the basis of data from: The Handbook of Basic Economic Statistics, July 1978. Washington D. C., Bureau of Economic Statistics Inc. Data for the first three variables were available for the period 1939-1977, and for 1947-1977 for the last two.

than capital owners). It is in these very terms that we can understand why excess profits taxes were introduced during both World War II and the Korean War (and were implicitly threatened during the Vietnam involvement).

Labor has not benefited equally across all sectors of productive activity and some notion of the distribution of war-induced gains should make the picture more complete. Figure 3 provides information on the difference between mean wartime and peacetime percentage growth rates in average weekly earnings for the following sectors: 1) durable goods, 2) nondurable goods, 3) machinery, 4) electric goods and electronic 
machinery and, 5) transportation equipment. While the categories are not always mutually exclusive, the data indicate that while each of the sectors has gained, in overall terms, the durable goods sector has tended to fare relatively best in wartime while the difference is very slight in transportation and electronics.

The empirical evidence is thus reasonably clear and the gains of labor relative to capital can be accounted for by the joint requirement of economics and politics in wartime. The question which logically follows on the heels of this analysis concerns the implications of these effects for the actual incidence and expansion of wars. Establishing the apparent bases of objective economic interests is no doubt of substantive importance to political theory in and of itself. The discipline would, however, not progress very far if the actual links between these interests and political attitudes and action remained a mystery. In this particular case, the following two questions are especially relevant. To what extent, first of all, have anticipated economic gains affected the likelihood that the United States would engage in warfare? How much, furthermore, have actually experienced economic effects influenced the expansion or duration of military engagement? These are two logically distinct though empirically related matters, and dealing with either adequately would call for a research endeavour of at least the same magnitude as that already reported here. Nevertheless, some preliminary suggestions should be useful as they might, if taken in an appropriately tentative light, put our findings in relevant political perspective.

\section{Economic interests and national war involvement}

It seems unlikely, both on the basis of existing documentary evidence and of extant empirical research on the causes of war, that a principal concern of those who have committed the United States to its recent wars has been to jack up aggregate demand or, if one prefers, to increase surplus absorption.
Nor can it be plausibly maintained that an overriding impetus of warfare has originated from a desire to increase labor's share of national income relative to that of capital. Few political scientists would disagree and no Keynesian nor sophisticated contemporary Marxian has argued otherwise. In each case, factors such as strategic concerns, perceived international political interests, and even ideological fervor appear to have governed the decision to engage in open warfare. The fact that such concerns often seem misguided in retrospect does not detract from their salience at the time when the crucial decisions were taken.

The role of economic factors should not, of course, be totally discarded. There is indeed no reason to doubt that there was an awareness of the likely economic consequences of war and this may have created a context which made it easier to respond to other concerns by engaging in active belligerence. In other words, while not providing the independent motive, the anticipation of such consequences might have lessened resistance to military involvement abroad. It is logically not indifferent whether an impetus to action is provided or whether resistance to action is mitigated. From a practical viewpoint, however, the effects may often be equivalent.

The second question appears more open. Once they were actually experienced, economic effects may have influenced the expansion or duration of U.S. participation in conflict there where it had already (for whatever initial reasons) committed itself. ${ }^{19}$ There rarely is, as Joyce Kolko points out, 'an explicit decision to start a war to pull an economy out of a recession. There is simply an economic environment which encourages, or does not discourage, an expansion of conflict.' ${ }^{20}$ Thus, once a conflict reaches the stage of active warfare, the level of national economic performance may increase visibly and certain redistributive effects may be felt; these in turn may then influence the commitment to further military involvement. Here also, economic considerations should not be made to carry an overly heavy ex- 
planatory burden. Even limited wars impose very onerous costs on powerful nations and, in the American case, this was reflected in the general decline in public support for military involvement as the wars progressed. ${ }^{21}$ If, however, these costs could be controlled for, one would expect economic variables to play a discernible role - at least to the extent of retarding the decline in official resolve and in public support for the venture.

In view of the emphasis of this study, it would be useful to provide some suggestions concerning the attitudes of both businessmen and wage earners (as major parts of the constituency to which policy makers must be responsive) toward continued warfare. A direct and simple link between their preferences and actual foreign policy outputs would not be expected, yet an understanding of the interests and desires of major social groups is necessary to comprehend the political context within which decisions to expand or terminate conflicts are taken and to which such decisions must be responsive.

We will begin with business, i. e., with that sector of society which derives a substantial portion of its income from profits on capital. On the basis of what has been said so far, and assuming (as most social scientists quite justifiably do) that relative position is at least as important as absolute position, one would expect to observe a declining enthusiasm for continued war involvement as its effects on the distribution of national income become evident. Most of the available evidence would seem to support this suggestion. Public opinion data, for example, indicate that within the occupational category described as 'professional and business' in March of 1966 , only $28 \%$ of the respondents felt that the Vietnam war was a mistake; by October 1969, however, this figure had grown to $59 \% .22$

Attitudes of business toward war expansion or continuation are also evident in the movements of stock prices during wartime and, here too, the evidence points in the expected direction. A study conducted by
Hansen and Russett on the responses of the stock market to escalatory and conciliatory moves during the Vietnam War concluded that, by the end of 1967, the American financial community clearly desired a deescalation of the war. ${ }^{23}$ The fact that this runs counter to much of the rhetoric of the time makes it particularly interesting and, by March of 1968 , The Wall Street Journal could claim with some justification that: 'One of the more impressive demonstrations of antiwar feeling is underway these days in about the last place that peace marchers would look for it - Wall Street.' ${ }^{24}$ Such was not the case from the outset of the war. In mid-1965, with the first major commitment of combat troops to Vietnam, the Dow-Jones industrial average rose from a moderately high level of 861 in late July 1965 , to a historic high of 995.15 on February 91966 , as the war seemed to be providing a boost to the economy in the eyes of many investors. Yet, within a relatively short time, escalatory moves were followed by dips in the market (and vice-versa). In many ways, of course, business fared better during Vietnam than during either World War II or the Korean War, since neither price controls nor excess profits taxes were imposed. Nevertheless, labor costs did rise with tight labor markets, creating inflationary pressures and squeezing profits as the war progressed. By 1968, for example, the business press tended to complain that the inflationary spiral was due to increases in average rates of employee compensation which were far in excess of productivity growth, and that this escalating wage bill could not be offset by corresponding price boosts (presumably because of a fear of provoking the introduction of price controls)..$^{25}$

Altogether (and on the basis of an admittedly limited evidential base), there is reason to believe that while businessmen might not be entirely averse to a short and limited war, they do not view prolongued military involvement as being in their best interests. While this may be incongruent with 
many extant beliefs, it is interesting to note that even as radical an author as Yoyce Kolko should suggest that the decision to halt the escalation of the Vietnam War was due to the concerted pressure of American corporate businessmen. ${ }^{26}$

What about labor? A preliminary distinction ought, in the first place, to be made between wage earners as individuals and the organized unions which are meant to represent their interests in the political arena. No real evidence of which this author is aware suggests that the former are more hawkish than businessmen in their attitudes toward the nation's limited wars. ${ }^{27}$ Furthermore, public opinion surveys on the Vietnam War indicate that both blue collar and white collar workers withdrew their support at a rate which was comparable to that of businessmen. According to the Gallup Organization, in March 1966 only $22 \%$ of the respondents identified as 'manual workers' and $25 \%$ qualified as 'white collar' believed that sending troops to Vietnam had been a mistake; by October of 1969 this percentage rose to $56 \%$ for both groups. ${ }^{28}$ It is, on the other hand, rather well known that the support of organized labor never flagged. ${ }^{29}$ While, given the supportive general mood, one would have expected such attitudes during World War II and the Korean War, the extent of the backing provided by the unions for the Vietnam venture, at a time when it came under powerful domestic criticism, strongly suggests that most of them realized where the interests of their constituents lay. In fact, few major American organizations provided the administration with as stalwart an endorsement on Vietnam as did the A.F.L. - C.I.O. and, with minor internal dissent, ${ }^{30}$ this support lasted from the initial commitment until ultimate withdrawal. While isolated quotations should certainly be taken with a pinch of salt, a statement by the president of Communication Workers of America on the occasion of President Nixon's invasion of Cambodia is too revealing in its bluntness to be relegated to the obscurity of a footnote:
Suppose last night, instead of escalating into Cambodia, President Nixon (had) said we are pulling every man out in the quickest manner This morning, the Pentagon would have notified thousands of corporations and said 'your contract is cancelled' - by tomorrow millions would be laid off. 31

What can we conclude about the attitudes toward foreign military involvement? While the empirical basis used here has admittedly been impressionistic, three tentative inferences are indicated. In the first place, faced with eroding rates of profit, due in part to rising labor costs, and with actual or feared governmental regulation, business is not likely to support a lengthy war. Organized labor, on the other hand, tends to be a reliable backer of military intervention presumably because of its effects on wages, employment, and the redistribution of national income from capital to labor. Finally, the individual wage earner appears less likely to possess attitudes which are predictable on the basis of simple economic considerations.

\section{Concluding remarks}

Despite the apparent benefits accruing to wage earners, i. e., the bulk of the American public, the progressive decline in support for warfare has been noteworthy..$^{32}$ Nonetheless, had somewhat different circumstances prevailed, economic concerns might have been more decisive. Neither Korea nor Vietnam came on the heels of a major recession, and even World War II occurred after the nation had emerged from the trough of the Great Depression. Had they immediately followed such periods, inflationary pressures might not have threatened businessmen and increased military production would have provided an even greater blessing as far as employment levels were concerned. There is yet another reason why the vectors of prevailing economic interests did not, as might have been expected, decisively favor continued military involvement. It has been pointed out that there was, in most cases, a realization that military spending would not 
drop back to pre-war levels after the termination of hostilities. As Hansen and Russett maintain, high levels of peacetime military spending and the contracts involved may represent, for the businessman, a more practical and less risky alternative to actual warfare. $^{33}$ In the case of Vietnam, this suggestion is further buttressed by the fact that, during the final phases of the war, the financial press tended to invoke the prospect of continued high levels of defense spending and the development of new strategic systems to discount the risk of a post-war recession. ${ }^{34}$ There was thus little to lose and something to gain if belligerence were ended. In fact, as far as peacetime military outlays are concerned, there may be no discrepancy between the interests of capital owners and wage earners. Organized labor has, indeed, been as resolute a supporter of peacetime defense spending at it has been of actual military involvements - a support which has ranged from general clamors for military preparedness to the endorsement of specific weapons systems. ${ }^{35}$

The conclusion is therefore that, under somewhat different conditions (a preceding recession or no prospects of massive defense outlays after the war), economic concerns may have had an even weightier effect on military involvement abroad. Nonetheless, it should be stressed that in the absence of absolute and relative material gains for some major social categories, decisions to engage in hostilities (for whatever initial reason) may have been harder to take in the first place and the scope and duration of wars may have been lesser.

A final, and perhaps unnecessary, word of caution. In no case has the research presented here been as exhaustive, nor the methodology as sophisticated, as would have been appropriate in a longer and more ambitious study. The research does, however, point to certain well defined conclusions and these in turn seem to trace the first contours of a coherent picture. Thus, while the utility of this study is hopefully more than just heuristic, considerably more work will be needed for a comprehensive and wholly compelling story to emerge.

\section{NOTES}

1. For example: J. David Singer and Melvin Small, The Wages of War (John Wiley: New York, 1972) and Manus I. Midlarsky, On War: Political Violence in the International System (The Free Press: New York, 1975).

2. One of the best examples of such work is: Nazli Choucri and Robert C. North, Nations in Conflict: National Growth and International Violence (W. H. Freeman and Co.: San Francisco: 1974).

3. There have been several attempts at casting some of the propositions contained in Lewis $\mathbf{A}$. Coser, The Functions of Social Conflict (The Free Press: New York, 1964) in a form which would make them relate more specifically to warfare. Kenneth Organski and Jacek Kugler have recently tested the hypothesis that, in terms of aggregate economic power, loser nations eventually outstrip the winners in 'The Costs of Major Wars: The Phoenix Factor' American Political Science Review (71,4, December 1977): 1347-1366. The classic, and extremely general, historical work on the consequences of war is by John C. Nef, War and Human Progress (Harvard University Press: Cambridge, 1950).

4. Four recent and representative works are: Michael H. Best and William E. Connoly, The Politicized Economy (D. C. Heath: Lexington, 1976); Bruno S. Frey, Modern Political Economy (Martin Robertson: Oxford, 1978); Charles E. Lindblom, Politics and Markets (Basis Books: New York, 1977); and, Edward R. Tufte, Political Control of the Economy (Princeton University Press: Princeton, 1978).

5. Monthly Review Press: New York, 1966.

6. Ibid p. 9.

7. The United States has, of course, been less willing to accept substantial governmental economic participation than have many other liberal democracies. In this respect, among others, it might be considered more difficult to control putative stagnationist tendencies than in certain countries (such as West Germany and Japan) which have experienced several decades of steady growth without either wars or large scale military spending.

8. Some further discussion is provided in Eliot Janeway, The Economics of Crisis: War, Politics and the Dollar (Weybright and Talley: New York, 1968) as well as in Victor Perlo, The Unstable Economy: Booms and Recessions in the United States since 1945 (Lawrence and Wishart: London, 1973). 
9. Arthur H. Okun, The Political Economy of Prosperity (W. W. Norton and Co.: New York, 1970) p. 66.

10. Ibid, p. 67.

11. For purposes of this study, 'labor' is defined as that productive activity which is provided principally in exchange for a wage.

12. Relevant passages are presented in Robert Freedman ed., Marx on Economics (Harcourt, Brace and World: New York, 1961), pp. 168-184.

13. Michael Kalecki, Selected Essays on the Dynamics of the Capitalist Economy (Cambridge University Press: Cambridge, 1971, especially pp. 138-141.

14. These arguments are summarized in Edmund S. Phelps, Inflation Policy and Unemployment Theory (MacMillan: London, 1972).

15. 'Relative Movements in Wages and Profits', Federal Reserve Bank of St. Louis Review (February, 1973), pp. 8-16.

16. 'Economic Interest and the Politics of Macroeconomic Policy', mimeo. Center for International Studies, Massachusetts Institute of Technology, 1976.

17. See William D. Nordhaus, 'The Falling Share of Profits', Brooking Papers on Economic Activity, (No. 1, 1974), pp. 169-217.

18. For the opposite view concerning the Vietnam War, see Thomas Riddel, 'The Economic Effects of the War in Vietnam'. In 'The War and its Impact on the Economy'. Review of Radical Political Economics, August 1970, pp. 41-53.

19. The distinction between the two aspects is not always clearcut, as is evidenced by the Vietnam War where a restricted amount of military aid and advice to the Saigon regime led to full scale U.S. warfare against the National Liberation Front and North Vietnam. If one is willing to accept as a bench mark the year 1965, it can be argued that a perception of incidental economic gain during the early stages of the involvement led to the expansion of the military effort in order to reap further and increased benefits. While it is impossible to settle the issue in a definitive manner, some tentative suggestions can be made. The assertion might, for example, be buttressed by the fact that the U.S. economy had experienced a relatively severe recession in 1960 and 1961 which was followed by a recovery which coincided with the first steps taken in Vietnam. This coincidence, it can be argued, influenced the decisions which ultimately led to massive escalation three years later. On the other hand, two counterarguments could be advanced. In the first place, the scale of the entanglement during these early years was too small to have done much to encourage the recovery. Secondly, the tax cut, which was introduced in 1964, with the idea of boosting consumer spending, had already begun to produce the desired expansionary effects in the first half of 1965 - a fact which may make it unlikely that the decision to send a large number of troops to Vietnam of July 1965 could have had an essentially economic purpose.

20. Joyce A. Kolko, American and the Crisis of World Capitalism (Beacon Press: Boston).

21. See below, page 24 and fn. 31 .

22. Data is from the source in footnote 27.

'Testing Some Economic Interpretations of American Intervention: Korea, Indochina and the Stock Market', in Steven Rosen ed., Testing the Theory of the Military Industrial Complex (D. C. Heath and Co.: Lexington, 1973).

24. 'Intensification of War in Vietnam. Causes Big Stock-Price Drops', Wall Street Journal (March 11, 1968) p. 1.

25. Ibid. See also, 'Labor Keeps the Wage Pressure On', Business Week (April 5, 1969) p. 17. 26. Kolko, op. cit.

27. For some statistical work on this point, see Bruce M. Russett and Miroslav Nincic, 'American Opinion on The Use of Military Force Abroad' Political Science Quarterly (91,3, Fall 1976) pp. 411-431.

28. These results, as well as those concerning businessmen reported above (pp. 20-21), are based on responses to the following question: 'In view of the developments since we entered the fighting in Vietnam, do you think the U.S. made a mistake sendings troops to fight in Vietnam?'. The data are reported in Hazel Erskine, 'Is the War a Mistake?' The Public Opinion Quarterly. Vol.34, pp. 20-21.

29. The best source on this matter is Ronald Radosh, American Labor and United States Foreign Policy (Random House: New York, 1969). Repeated statements of support from the AFL-CIO for the Vietnam War can be found in various issues of A.F.L.-C.I.O. Free Trade Union News.

30. Most notably on the part of Victor Reuther of the U.A.W. who adopted a more moderate stance than did George Meany or the Executive Board of the A.F.L. - C.I.O.

31. Quoted in Barry B. Hughes, The Domestic Context of American Foreign Policy (W. H. Freeman: San Francisco, 1978) p. 167.

32. For example during the wars in Korea and Vietnam, these are the percentages of respondents who replied affirmatively to the question of whether American involvement was a mistake:

$\begin{array}{ccc}\text { Kugust }-50 & \text { o r e a : } & \\ 20 \% & \text { January }-51 & \text { April }-52 \\ & 49 \% & 51 \%\end{array}$

$\mathrm{V}$ i e $\mathrm{t} \mathbf{n}$ a $\mathrm{m}$ :

August -65 Oct. -67 Oct. -68 Oct. -69 July -70 $24 \% \quad 46 \% \quad 54 \% \quad 58 \% \quad 61 \%$ 
(data are from Erskine op. cit. pp. 138-149). For further data and discussion, see, John E. Mueller, War, President and Public Opinion (John Wiley: New York, 1973). While the present author does not have time series data for World War II, a Gallup survey of February 1944 in which a similar question was asked ('Do you think that in years to come people will say the United States should have avoided getting into this war?') an affirmative response of $31 \%$ was elicited (smaller than for the other wars, but it gives no feeling for the trend during the war (reported in Erskine, p. 137).

33. Hansen and Russett, op. cit. p. 243.
34. Representative articles are: 'The Economy After Vietnam', The Wall Street Journal (April 18, 1968) p. 18; 'The Price of Arms Control', Business Week (July 12, 1969) pp. 64-70; 'War End Expected to Give U.S. Business a Psychological Lift', The Wall Street Journal (January 24, 1978) p. 1.

35. For example: the AFL-CIO's opposition to cuts in overseas troops and its support for the Trident nuclear submarine are stated in Labor Looks at Congress, 1973, p. 104; its endorsement of the B-1 bomber is vioced in Labor Looks at Congress 1977, p. 85. 